\title{
Ülkemizdeki Maden Sektöründe Meydana Gelen İş Kazası ve Meslek Hastalıklarının Analizi
}

\author{
Niyazi BİLIM ${ }^{* 1}$, Sertaç DÜNDAR ${ }^{1}$, Atiye BİLİM ${ }^{2}$ \\ ${ }^{1}$ Konya Teknik Üniversitesi, Maden Mühendisliği, Konya \\ ${ }^{2}$ Konya Teknik Üniversitesi, İş Sağllğ
}

\begin{abstract}
$\ddot{O} \mathbf{z}$
Madencilik sektörü dünyada kişi başına iş kazası oranlarının en büyük olduğu sektörlerden birisidir. Ülkemizdeki durumda da dünyadaki ile örtüşmektedir. Çünkü madencilik sektörü doğası gereği en riskli iş kollarından bir tanesidir. $\mathrm{Bu}$ nedenle, bu sektörde çalışanlar daha dikkatli olmak zorundadır. Ülkemizde meydana gelen iş kazalarının madenlerde azaltılmasına yönelik son yıllarda devletin ve işverenlerin gerçekleştirdiği önemli ve umut verici olumlu gelişmeler kaydedilmiştir. Özellikle maden işyerleri için ek önlem paketleri getirilmiş ve güvenlik kültürünün oturtulması yönünde çalışmalar hızlandırılmıştır. Bu çalışmada, madencilik sektöründe 2012-2016 yıllarında (son beş yıl) meydana gelen iş kazaları ve meslek hastalıkları ana ve alt sektörler ile birlikte ayrıntılı analiz edilmiştir. İş kazası analizlerinde önemli bir gösterge olan kaza olabilirlik oranı, maden sektöründeki ana ve alt sektörlerle birlikte belirlenerek değerlendirilmiștir. Maden sektörünün iş güvenliği açısından durumu diğer bazı sektörler ile karşılaştırılarak yorumlar yapılmıştır. Sonuçta; iş kazalarında az da olsa bir azalma eğilimine girildiği görülmekte olup, bunun daha yüksek bir düşüş eğilimine girebilmesi için yapılması gerekenler noktasında bazı önerilerde bulunulmuştur.
\end{abstract}

Anahtar kelimeler: İş kazası, maden kazası, iş güvenliği, meslek hastalığı.

\section{Analysis of Occupational Accident and Disease in the Mining Sector in Turkey}

\begin{abstract}
Mining industry is one of the sector that work-related accidents rates per person are the highest. The situation in our country overlaps with that in the world. Mining is one of the most risky sector because of work conditions. For his reason employees have to be more careful. In recent years state and employers have developed significant and promising improvements in order to reduce work accidents in mining. Especially for mining additional safety precautions have been developed to improve safety culture. In this study, work accidents and occupational diseases that occurred in the mining industry over the 2012-2016 (last five years) years were analyzed in detail together with main and sub-sectors. Incidence rates which is important indicator in analysis of work accidents has been evaluated together with the main and sub-sectors in the mining sector. The situation of mining sector has been compared with some other sectors. As a result, it appears that there is a slight tendency to decrease in work accidents, and some suggestions have been made in order to make it a higher tendency to decline.
\end{abstract}

Keywords: Work accident, mine accident, work safety, occupational disease.

\section{Giriş}

Modern yaşamı destekleyen dünyanın en eski sektörlerinden ve en önemlilerinden birisi hiç kuşkusuz ki madencilik sektörüdür. Madencilik olmadan bugünün dünyasını hayal etmek imkânsızdır.

\footnotetext{
*Sorumlu yazar: bilim@selcuk.edu.tr

Geliş Tarihi: 22.06.2018, Kabul Tarihi: 27.11.2018
} 
Madencilik, tarih boyunca uygarlıkları şekillendiren temel sektörlerden biri olmuştur. Günümüzde madencilik faaliyetleri olmaksızın insan yaşamının sürdürülebilmesi çok zordur. Çünkü kullandığımız taşıtlardan, içinde yaşadığımız evlere, bilgisayarlardan telefonlara kadar yaşamımız için vazgeçilmez olan hemen her şey, madencilik etkinlikleri sonucu elde edilmektedir [1]. Madencilik sektörü, ülkelerin istihdam sorunlarına ve ekonomik gelişimlerine katkı sağlamaları nedeniyle çok önemli bir sektördür. Ancak, bu sektör iş sağlığı ve güvenliği açısından dünya genelinde en riskli sektör olarak kabul edilir. Çünkü çalışılan ortamda çok fazla risk ve tehlike bulunmakta ve bunların hepsinin değerlendirilmesi ve önlenmesi çok kolay olmamaktadır. Maden işyerlerinde sağlıklı ve güvenli bir işyeri şartları sağlamak için, iş sağlığı ve güvenliği sisteminin kurulması, uygulanması, denetlenmesi ve sürekli iyileştirilmesi gereklidir. Ayrıca maden işyerlerindeki tehlike ve riskler bazen sabit olmayıp hareketli ve değişken olabilmektedir. Bu tür durumlarından üstesinden gelebilecek tedbirlerin ve yöntemlerin işletme için geliştirilmesi gereklidir.

Ağır iş makinelerinin kullanıldığ 1 yeraltı ve yerüstü maden işletmelerinde kalifiye eleman istihdamının yetersizliği, makinelerin periyodik bakımlarının yapılmasındaki aksaklıklar ve yapılan hatalı işletme yöntemleri iş kazası ve meslek hastalıklarının artmasına sebep olabilmektedir [2]. Madenciliğin tüm bu zor koşullarına rağmen günümüzde gelişen teknoloji ile beraber bu risklerin bertaraf edilmesi veya en aza indirilmesi mümkündür.

Son yıllarda tıpkı dünyanın geri kalanında olduğu gibi Türkiye'de de, kömür, gümüş, altın, manganez, bakır ve krom cevherleri için madencilik faaliyetleri artmıştır [3, 4]. Ayrıca, ülkemizin elektrik enerji ihtiyacının milli kaynaklar ile karşılanması için yerli kaynaklara bir yönelme eğilimi hızlanmıştır. Bu nedenle son yıllarda kömür yakıtlı termik santrallerin artmasına paralel olarak kömür üretim miktarlarında da artışlar gerçekleşmiştir. Üretimdeki bu artışın iş kazalarına yansımaması için ek önlemlerin alınması gerekliliği doğmuştur. Ülkemizde iş kazaları sektörel bazda incelendiğinde, iş kazalarının 2016 yılında \%4,12 olarak madencilik sektöründe olduğu görülmektedir. Ülkemizde maden sektöründe iş kazaları ile sık karşılaşılmasının ana sebepleri; iş sağlığı ve güvenliği prosedürlerinin tam olarak oturtulamamış olması, uygulama ve denetimlerdeki eksiklikler ve ülkemizdeki maden ocaklarının bir kısmının jeolojik yapı itibarıyla bazı riskler barındırmasıdır [5]. Madencilik sektörü içerisinde en riskli olan ise kömür madenciliğidir. Kömür madenciliği içerisinde özellikle de yeraltı kömür madenciliği dünya genelinde en riskli sektörlerden biri olarak tanınır [6], [7]. Madencilik faaliyetleri ortam şartları nedeniyle sürekli değişim göstermektedir. Değişen ortam şartlarına göre çalışmak, farklılık arz eden jeolojik yapılarda üretim yapmak, doğa ile mücadele etmek sektörünü diğer iş kollarından ayırmaktadır. Madencilik sektörünün bu önemli özellikleri iş sağlığı ve güvenliği uygulamalarını da önemli kılmaktadır.

Ülkemizde madencilik sektöründe toplam 132490 kişi istihdam edilmektedir. Tüm sigortalı çalışan nüfusun \% 0,96'sı madencilik sektöründe çalışmaktadır [8]. Ülkemizin gelişimi ve istihdam için çok önemli bir sektör olan madencilik sektörünün desteklenmesi iş kazalarının azaltılması için gerekli çalışmaların tüm paydaşlar tarafından gerçekleştirilmesi gereklidir. Son yıllarda yapılan olumlu gelişmeler daha iyi bir geleceğin bizi beklediği konusunda umutları yeşertmektedir.

Ülkemizdeki diğer sektörler ile maden sektöründeki her 100 kişi başına düşen iş kazası oranlarının karşılaştırılması yapıldığında birinci sırada maden sektörü, onu metal/makine ve inşaat sektörü takip etmektedir. Ayrıca, madencilik sektöründe işletme büyüklüğü arttıkça iş kazalarının azaldığı belirlenmiştir [9]. Arıtan ve Ataman [10], bir açık maden ocağında gerçekleştirdikleri iş kazası analizlerinde, kazaların çoğunun önlenebilir kazaların olduğunu ve kazaların çoğunun kişisel hatalardan kaynaklandığını vurgulamışlardır. Ayrıca, iş kazası analizlerinde kaza olabilirlik oranı (hızı), kaza ağırlık oranı (hızı) ve kaza olabilirlik oranının önemli parametreler olduğunu ifade etmişlerdir. Ceylan [11] yapmış olduğu çalışmada, 2004-2010 yıllarında Türkiye'de meydana gelen iş kazalarını sektörel bazda incelemiştir. Türkiye'de meydana gelen iş kazalarının \% 46, 4'ünün ve buna bağlı ölümlerin $\% 41,1$ 'inin maden, inşaat ve metal sektöründe meydana geldiğini belirtmiştir. İş kazalarının büyük bir çoğunluğu yalnızca üç sektörde gerçekleştiği görülmektedir.

İş kazası meslek hastalıklarından dolayı dünyada yılda milyonlarca kişi ölmekte, yaralanmakta veya sakat kalmaktadır. İş kazasına maruz kalan kişi ve yakınları için psikolojik travmalara ve diğer birçok sorunlara neden olmaktadır. Ayrıca kişilerin yakınları ve ülke için işgücü kaybı ve maddi kayıpları da beraberinde getirmektedir. ILO [12] verilerine göre her 15 saniyede bir çalışan iş kazası veya meslek hastalıklarına bağlı olarak hayatını kaybetmekte ve her 15 saniyede 153 çalışan iş kazası geçirmektedir. Yılda 160 milyondan fazla kişi iş kazası ve meslek hastalığına maruz kalmakta ve 313 
milyon ölümcül olmayan iş kazası meydana gelmektedir. Ekonomik açıdan bakıldığında, her yıl küresel gayri safi yurt içi hasılanın \%3,94'ü iş kazaları ve meslek hastalıkların bir sonucu olarak kaybolmaktadır. Yılda 2,78 milyondan fazla kişi iş kazaları ve meslek hastalıkları sonucu ölmektedir. Ayrıca yılda 374 milyondan fazla ölümlü olmayan iş kazası ve meslek hastalığı meydana gelmektedir [12].

Bu çalışmada, son beş yıl içerisinde Türkiye'de madencilik sektöründe meydana gelen iş kazası ve meslek hastalıklarının yıllara göre analizi gerçekleştirilmiştir. Çalışmada kullanılan tüm veriler Sosyal Güvenlik Kurumu (SGK) tarafından paylaşılan istatistik yıllıklarından türetilmiştir [8]. Ayrıca, SGK istatistik yıllıklarında 2013-2016 y1llarında sektör bazında ayrıntılı istatistikler verildiğinden bu yıllardaki veriler alt sektörlerle beraber detaylı bir şekilde değerlendirilmiştir. Analizler sonucunda bulunan bulgular ışığında, madencilik sektöründe meydana gelen iş kazası ve meslek hastalıkları ile ilgili detaylı bilgiler ve bunların azaltılması ve dikkat edilmesi gereken parametreler konusunda öneriler sunulmuştur.

\section{2. İş Kazalarının Analizi}

Bu çalışmada ülkemizdeki maden işletmelerinde meydana gelen iş kazalarının ayrıntılı bir şekilde 20122016 yılları arası analiz edilmiştir. Bu yılların analiz edilmesinin ana sebebi, Sosyal Güvenlik Kurumu (SGK)'nın ana sektörler yanında alt sektörlerinde istatistiklerinin bu yıllarda ayrıntılı bir şekilde sunmaya başlamasındandır.

Madencilik faaliyetlerinin ana grupları içerisindeki iş kazalarının dağılımını analiz edebilmek amacıyla Tablo 1 oluşturulmuştur. Tablo 1'de 2012-2016 yılları arasında meydana gelen iş kazalarının madencilik sektöründeki ana gruplar içeresindeki durumu sunulmuştur. Madenlerde meydana gelen iş kazalarının büyük bir kısmının kömür madenciliğinde gerçekleştiği görülmektedir. Son beş yılda maden sektöründe meydana gelen iş kazalarının ortalamasına göre bir değerlendirme yapıldığında, iş kazalarının yaklaşık \% 77'si kömür madenciliğinde (Kömür ve linyit çıkartması) gerçekleşmiştir. Kömür madenciliğini "Diğer madencilik ve taş ocakçılı̆̆ı" izlerken, en az kazanın olduğu sektör ise "Ham petrol ve doğalgaz çıkarımı" dır.

Tablo 1. 2012-2016 yılları arasında maden işletmelerinde meydana gelen iş kazası sayıları

\begin{tabular}{|c|c|c|c|c|c|c|}
\hline \multirow[t]{2}{*}{ Faaliyet Türü } & \multicolumn{5}{|c|}{ Yillar } & \multirow[t]{2}{*}{ Ortalama } \\
\hline & 2012 & 2013 & 2014 & 2015 & 2016 & \\
\hline Kömür ve Linyit Çıkartması & 8828 & 11289 & 10026 & 7429 & 8274 & 9169,2 \\
\hline $\begin{array}{l}\text { Ham Petrol ve Doğalgaz } \\
\text { Çıarımı }\end{array}$ & 44 & 118 & 165 & 84 & 112 & 104,6 \\
\hline Metal Cevheri Madenciliği & 421 & 1055 & 1030 & 997 & 1037 & 908,0 \\
\hline $\begin{array}{l}\text { Diğer Madencilik ve Taş } \\
\text { Ocakçllığ1 }\end{array}$ & 569 & 1598 & 1557 & 1639 & 2045 & 1481,6 \\
\hline $\begin{array}{l}\text { Madenciliği Destekleyen } \\
\text { Hizmet Faaliyetleri }\end{array}$ & 101 & 244 & 271 & 271 & 324 & 242,2 \\
\hline
\end{tabular}

Son beş y1l içerisinde madencilik sektöründe meydana gelen iş kazaları irdelendiğinde kömür madenciliğinde diğer madencilik faaliyetlerine göre çok yüksek miktarda iş kazası olduğu görülmektedir. Şekil 1'de son beş yıl içerisinde tüm madencilik faaliyetlerinde gerçekleşen iş kazası sayılarının ortalamaları gösterilmektedir. 


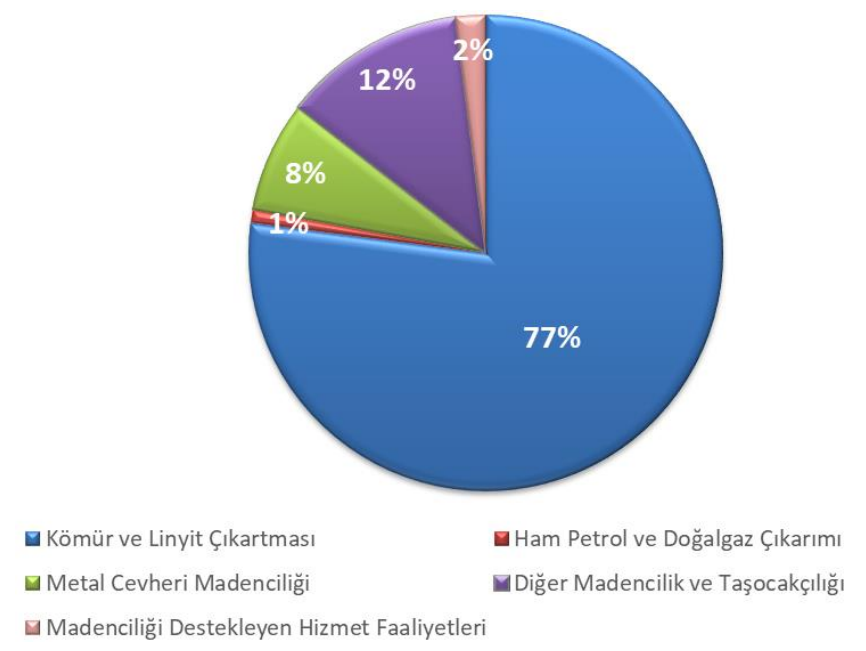

Şekil 1. Son beş yıl içerisinde ülkemizde madencilik faaliyetlerinde gerçekleşen iş kazalarının dağılımı

Tablo 2'de ise madencilik ile ilgili ana sektörler ve bu sektörlerin alt sektörlerinde gerçekleşen iş kazası sayıları ayrıntılı bir şekilde sunulmuştur. SGK' nın ana sektörlerin yanında alt sektörlerde meydana gelen iş kazası verilerini 2013 yılından itibaren paylaşması nedeniyle analizlerde 2012 yılı değerlendirmeye katılmamıştır. Son dört yılın verileri alt sektörlerle beraber değerlendirildiğinde belirgin bir değiş̧im görülmemektedir. Sadece bazı alt sektörlerde iş kazası olmamış ya da çok az meydana gelmiştir (Tablo 2).

Tablo 2. Ana madencilik sektörü ve alt sektörlerde meydana gelen iş kazası sayıları

\begin{tabular}{|c|c|c|c|c|}
\hline \multirow{2}{*}{ Faaliyet Alanları } & \multicolumn{4}{|c|}{ Yillar } \\
\hline & 2013 & 2014 & 2015 & 2016 \\
\hline Kömür ve Linyit Çıkartması & 11289 & 10026 & 7429 & 8274 \\
\hline > Taş Kömürü & 4390 & 3811 & 3268 & 3363 \\
\hline$>\quad$ Linyit Kömürü & 6895 & 6215 & 4161 & 4911 \\
\hline$>\quad$ Diğer Kömürlerin İşletmeciliği & 4 & 0 & 0 & 0 \\
\hline Ham Petrol ve Doğalgaz Çıkarımı & 118 & 165 & 84 & 112 \\
\hline$>$ Ham Petrol Çıkarımı & 113 & 160 & 80 & 98 \\
\hline > Doğalgaz Çıkarımı & 5 & 5 & 4 & 14 \\
\hline Metal Cevheri Madenciliği & 1055 & 1030 & 997 & 1037 \\
\hline$>$ Demir cevheri & 61 & 54 & 78 & 62 \\
\hline$>$ Demir diş1 & 908 & 913 & 861 & 920 \\
\hline$>$ Uranyum ve toryum & 86 & 63 & 58 & 55 \\
\hline Diğer Madencilik ve Taş ocakçılığı & 1598 & 1557 & 1639 & 2045 \\
\hline $\begin{array}{l}\text { Süsleme ve yapi taşlarının. Kireç taşı alçı taşı tebeşir ve } \\
\text { kayağan taşı (bileği taşı) ocakçılığı }\end{array}$ & 935 & 946 & 859 & 1044 \\
\hline $\begin{array}{l}\text { Çakıl ve kum ocaklarının faaliyetleri, kil ve kaolin (arı kil) } \\
\text { çıkarımı }\end{array}$ & 111 & 127 & 177 & 268 \\
\hline$>$ Kimyasal ve gübreleme amaçlı mineral madenciliği & 173 & 102 & 197 & 223 \\
\hline$>$ Turba çıkarımı ve briketlenmesi & 0 & 0 & 0 & 0 \\
\hline > Tuz çıkarımı & 11 & 14 & 19 & 17 \\
\hline$>$ Deniz ve göllerde tuz çıkarımı & 2 & 0 & 0 & 0 \\
\hline$>$ Kaya tuzu ve diğer tuzların çıkarımı & 3 & 2 & 0 & 0 \\
\hline $\begin{array}{l}\text { Genel maden arama işleri (Petrol ve tabii gaz arama işleri } \\
\text { hariç) }\end{array}$ & 29 & 5 & 0 & 0 \\
\hline $\begin{array}{l}\text { Müstakilen yapılan maden ve cüruf temizleme. ayıklama } \\
\text { işleri. }\end{array}$ & 41 & 3 & 0 & 0 \\
\hline $\begin{array}{l}\text { Başka yerde sınıflandırılmamış diğer madencilik ve taş } \\
\text { ocakçılığı }\end{array}$ & 293 & 358 & 387 & 493 \\
\hline Madenciliği Destekleyen Hizmet Faaliyetleri & 244 & 271 & 271 & 324 \\
\hline$>$ Petrol ve doğal gaz çıkarımını destekleyici faaliyetler & 118 & 57 & 45 & 56 \\
\hline $\begin{array}{l}\text { Madencilik ve taş ocakçılığını destekleyici diğer } \\
\text { faaliyetler }\end{array}$ & 126 & 214 & 226 & 268 \\
\hline
\end{tabular}




\section{Meslek Hastalıklarının Analizi}

Meslek hastalığına yakalanan çalışan sayısı iş kazalarında olduğu gibi, kömür madenciliği meslek hastalıklarının da en fazla karşılaşıldığı madencilik sektörüdür. Tablo 3'te 2012-2016 yılları arasında madencilik faaliyetlerinde gerçekleşen meslek hastalığı sayıları sunulmuştur. Meslek hastalığına yakalanan çalışan sayısı iş kazalarında olduğu gibi, kömür madenciliği meslek hastalıklarının da en fazla karşılaşıldığı madencilik sektörüdür. Maden sektöründe karşılaşılan meslek hastalıklarının yaklaşık \% 96's1 kömür madenciliğinde meydana gelmiş̦tir (Son 5 yılın ortalaması baz alındığında). "Ham petrol ve doğal gaz çıkarımı” sektöründe son beş yılda hiçbir meslek hastalığının yaşanmamıştır.

Tablo 3. 2012-2016 yılları arasında madencilik sektöründe meslek hastalığına yakalanan çalışan sayısı

\begin{tabular}{lcccccc}
\hline \multicolumn{1}{c}{ Faaliyet Türü } & $\mathbf{2 0 1 2}$ & $\mathbf{2 0 1 3}$ & $\mathbf{2 0 1 4}$ & $\mathbf{2 0 1 5}$ & $\mathbf{2 0 1 6}$ & Ortalama \\
Kömür ve Linyit Çıkartması & 231 & 42 & 19 & 84 & 74 & $\mathbf{9 0 , 0}$ \\
Ham Petrol ve Doğalgaz Çıkarımı & 0 & 0 & 0 & 0 & 0 & $\mathbf{0 , 0}$ \\
Metal Cevheri Madenciliği & 4 & 1 & 0 & 1 & 0 & $\mathbf{1 . 2}$ \\
Diğer Madencilik ve Taş Ocakçılığı & 1 & 0 & 2 & 2 & 3 & $\mathbf{1 , 6}$ \\
Madenciliği Destekleyen Hizmet Faaliyetleri & 0 & 1 & 0 & 0 & 2 & $\mathbf{0 , 6}$ \\
\hline
\end{tabular}

Tablo 4'te ise madencilik ile ilgili ana sektörler ve bu sektörlerin alt sektörlerinde meslek hastalıklarına yakalanan kişi sayıları ayrıntılı bir şekilde sunulmuştur. Meslek hastalığına yakalanma sayısı en fazla taş kömürü madenciliğindedir.

Tablo 4. Ana madencilik sektörü ve alt sektörlerde meslek hastalığına yakalanan kişi sayıları

\begin{tabular}{|c|c|c|c|c|}
\hline \multirow[b]{2}{*}{ Faaliyet Alanı } & \multicolumn{4}{|c|}{ Yillar } \\
\hline & 2013 & 2014 & 2015 & 2016 \\
\hline Kömür ve Linyit Çıkartması & 42 & 19 & 84 & 74 \\
\hline > Taş Kömürü & 42 & 18 & 84 & 70 \\
\hline$>\quad$ Linyit Kömürü & 0 & 1 & 0 & 4 \\
\hline$>\quad$ Diğer Kömürlerin İşletmeciliği & 0 & 0 & 0 & 0 \\
\hline Ham Petrol ve Doğalgaz Çıkarımı & $\mathbf{0}$ & $\mathbf{0}$ & $\mathbf{0}$ & $\mathbf{0}$ \\
\hline$>$ Ham Petrol Çıkarımı & 0 & 0 & 0 & 0 \\
\hline > Doğalgaz Çıkarımı & 0 & 0 & 0 & 0 \\
\hline Metal Cevheri Madenciliği & 1 & $\mathbf{0}$ & 1 & $\mathbf{0}$ \\
\hline$>$ Demir Cevheri & 0 & 0 & 0 & 0 \\
\hline$>$ Demir Dış1 & 1 & 0 & 1 & 0 \\
\hline$>$ Uranyum ve Toryum & 0 & 0 & 0 & 0 \\
\hline Diğer Madencilik ve Taşocakçılığı & $\mathbf{0}$ & 2 & 2 & 3 \\
\hline $\begin{array}{l}\text { Süsleme ve yapı taşlarının. Kireç taşı alçı taşı tebeşir ve } \\
\text { kayağan taşı (bileği taşı) ocakçlığ } 1\end{array}$ & 0 & 1 & 0 & 1 \\
\hline $\begin{array}{l}\text { Çakıl ve kum ocaklarının faaliyetleri, kil ve kaolin (arı kil) } \\
\text { çıkarımı }\end{array}$ & 0 & 1 & 2 & 1 \\
\hline$>$ Kimyasal ve gübreleme amaçlı mineral madenciliği & 0 & 0 & 0 & 0 \\
\hline > Turba çıkarımı ve briketlenmesi & 0 & 0 & 0 & 0 \\
\hline$>$ Tuz çıkarımı & 0 & 0 & 0 & 0 \\
\hline$>$ Deniz ve göllerde tuz çıkarımı & 0 & 0 & 0 & 0 \\
\hline$>$ Kaya tuzu ve diğer tuzların çıkarımı & 0 & 0 & 0 & 0 \\
\hline $\begin{array}{l}\text { Alelümum maden arama işleri (Petrol ve tabii gaz arama } \\
\text { işleri hariç) }\end{array}$ & 0 & 0 & 0 & 0 \\
\hline $\begin{array}{l}\text { Müstakilen yapılan maden ve curuf temizleme. ayıklama } \\
\text { işleri. }\end{array}$ & 0 & 0 & 0 & 0 \\
\hline $\begin{array}{l}\text { Başka yerde sınıflandırılmamış diğer madencilik ve } \\
\text { taşocakcılığ } 1\end{array}$ & 0 & 0 & 0 & 1 \\
\hline Madenciliği Destekleyen Hizmet Faaliyetleri & 1 & $\mathbf{0}$ & $\mathbf{0}$ & 2 \\
\hline$>$ Petrol ve doğal gaz çıkarımını destekleyici faaliyetler & 0 & 0 & 0 & 0 \\
\hline $\begin{array}{l}\text { Madencilik ve taş ocakçıllı̆ını destekleyici diğer } \\
\text { faaliyetler }\end{array}$ & 1 & 0 & 0 & 2 \\
\hline
\end{tabular}




\section{Kaza Olabilirlik Oranının Analizi}

Kaza verilerinin nicel analizinde, iş kazalarının incelenmesi ve kazalarla ilgili kıyaslamaların yapılması için yaygın olarak kaza sıklık hızı (oranı) ve kaza ağırlık hızı (oranı) ve kaza olabilirlik oranı göstergeleri kullanılmaktadır [13].

Emniyet performans göstergeleri kaza analizi ve önlenmesinde önemli bir rol oynayan, etkili kaza istatistiklerinin temelini oluşturur. $\mathrm{Bu}$ amaçla bu çalışmada genellikle kaza olabilirlik oranına göre değerlendirmeler yapılmıştır. Çünkü bir sektörde çalışan sayısının fazla olması, doğal olarak kaza sayısının da yüksekliğini beraberinde getirmektedir. Bu nedenle kişi başına düşen iş kazasının analizde kullanılması daha değerlendirilebilir bilgiler sunmaktadır.

Temel olarak kaza olabilirlik oranı, belirli bir zaman içerisinde bir hastalık durumunun gerçekleşme sıklığının ölçülmesidir. Genellikle kaza olabilirlik oranının hesaplanması için kullanılan eşitlik aşağıda sunulmuştur. Eşitlik 1'deki 100000 sayısı kişi sayısını ifade etmektedir. Bu nedenle bu değer farklı bir kişi sayısı ile değiştirilerek de analizler yapılabilir. Bu çalışmada kaza olabilirlik oranı hesaplanırken her 100 kişi başına düşen iş kazası ve ölüm oranları hesaplanmıştır. Başka bir ifade ile, sektörde çalışanların tümü içerisinde kaç kişinin kazaya maruz kaldığının belirlenebilmesi daha sade ve anlaşılır yorumlar için yüzde yaklaşımı tercih edilmiştir.

Kaza Olabilirlik Oranı $=\frac{\text { Kaza Sayısı (Ölümlü veya Ölümlü olmayan) }}{\text { Toplam Çalışan Sayısı }} \times 100000$

Maden sektöründe meydana gelen iş kazası ve meslek hastalıklarının daha ayrıntılı ve anlamlı değerlendirebilmek için kişi başına düşen iş kazası ve meslek hastalığının belirlenmesi gereklidir. Sadece sektörlerde meydana gelen iş kazası ve meslek hastalığı sayılarına göre değerlendirmeler yapmak, genel durumu görmek için yetersiz kalmaktadır. Çünkü bir sektörde meydana gelen iş kazasının çok olması, belki de o sektörde çok fazla çalışan kişi olmasından kaynaklanmaktadır. Bu nedenle, iş kazası analizlerinde "kaza olabilirlik oranı" kavramının kullanılması daha derin ve anlamlı değerlendirmelerin yapılmasına olanak tanımaktadır. Kaza olabilirlik oranı madencilik faaliyetlerinin alt kısımları olan, kömür ve linyit çıkartması, ham petrol ve doğalgaz çıkarımı, metal cevheri madenciliği, diğer madencilik ve taş ocakçılığı ve madenciliği destekleyen hizmet faaliyetleri için ayrı ayrı olarak belirlenmiş ve birbiri ile kıyaslanmıştır. Tablo 5'te toplam iş kazaları için kaza olabilirlik oranı gösterilmiştir. Burada, her 100 kişi başına düşen iş kazası sonuçları belirlenmiş ve sunulmuştur. 2012-2016 yılları tek tek incelenmiş ve ortalamaları sunulmuştur. Tablo 5'ten de görüldügüü gibi kömür madenciliğinde kaza olabilirlik oranı diğer madencilik faaliyetlerine göre çok daha yüksektir. Kömür madenlerinde çalışan beş kişiden bir tanesi iş kazasına maruz kalmaktadır (Tablo 5). Diğer madencilik türlerinde ise ortalama 100 çalışandan 3 tanesi iş kazasına uğramaktadır.

Tablo 5. 2012-2016 yılları arasında maden sektöründe gerçekleşen iş kazalarının kaza olabilirlik oranları

\begin{tabular}{lcccccc}
\hline \multicolumn{1}{c}{ Faaliyet Türüi } & \multicolumn{7}{c}{ *Kaza olabilirlik oranı } \\
& $\mathbf{2 0 1 2}$ & $\mathbf{2 0 1 3}$ & $\mathbf{2 0 1 4}$ & $\mathbf{2 0 1 5}$ & $\mathbf{2 0 1 6}$ & Ortalama \\
Kömür ve Linyit Çıkartması & 17,33 & 23,18 & 24,42 & 18,34 & 22,02 & $\mathbf{2 1 , 0 6}$ \\
Ham Petrol ve Doğalgaz Çıkarımı & 1,17 & 3,48 & 4,92 & 2,69 & 3,95 & $\mathbf{3 , 2 4}$ \\
Metal Cevheri Madenciliği & 1,87 & 4,39 & 4,40 & 4,45 & 4,51 & $\mathbf{3 , 9 2}$ \\
Diğer Madencilik ve Taş ocakçıllı̆ı & 0,97 & 2,62 & 2,77 & 2,74 & 3,33 & $\mathbf{2 , 4 9}$ \\
Madenciliği Destekleyen Hizmet Faaliyetleri & 1,94 & 3,42 & 3,29 & 4,56 & 4,27 & $\mathbf{3 , 5 0}$ \\
\hline
\end{tabular}

*Her 100 kişi başına düşen iş kazası sayısı

2012-2016 yılları arasında bütün madencilik faaliyetlerinde gerçekleşen iş kazalarının kaza olabilirlik oranı Şekil 2'de sunulmuştur. Kaza olabilirlik oranı hesaplanırken 100 kişi başına düşen iş kazas1 şeklinde hesaplanmıştır. 2013 ve 2014 yıllarında kaza olabilirlik oranının arttığını daha sonra 2015 yılında azaldığını ve 2016 yılında 2015 yılına göre arttığını fakat 2013 ve 2014 yıllarına göre daha 
düşük seviyede olduğunu görülmektedir. Son beş yıllık verilerin ortalaması alındığında, ortalama her yıl maden sektöründe çalışan her 100 kişiden 8,73'ü iş kazasına maruz kalmaktadır. Son yıllarda oranlarda bir düşüş olması ise sevindirici bir gelişmedir. Bu azalmanın nedenleri arasında, 2012 yılında çıkarılan 6331 sayılı "İş Sağlığ ve Güvenliği Kanunu" nun yürürlüğüğe girerek uygulanması ve 2014 yılından sonra "Madenlerde İş Sağlığı ve Yönetmeliğiı" yönetmeliğine eklenen ek maddelerin artıları olduğu söylebilir. Kömür madenlerinde mekanizasyona geçme çalışmalarının son yıllarda hızlanarak, mekanize kazı ve otomasyon sistemlerinin kullanımının artması diğer önemli bir sebeptir.

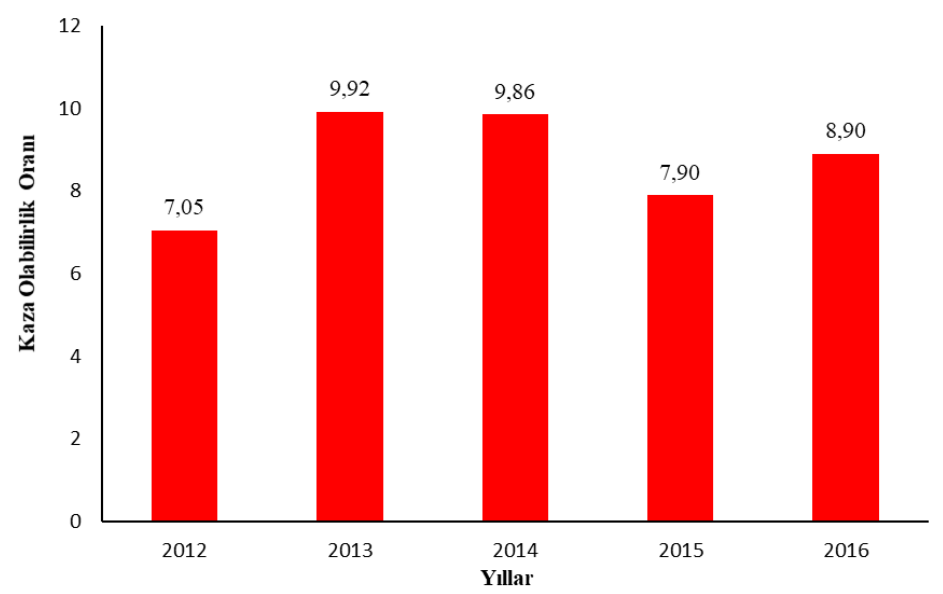

Şekil 2. Son 5 yılda madencilik faaliyetlerinde gerçekleşen iş kazalarının kaza olabilirlik oranı

Ülkemizde tüm sektörlerde meydana gelen iş kazaları içerisinde madencilik sektörünün payını belirleyebilmek amacıyla analizler gerçekleştirilerek, Şekil 3'te durum özetlenmiştir. Şekil 3'te görüldüğü gibi tüm iş kazaları içerisinde madencilik sektöründe gerçekleşen iş kazalarının oranı giderek azalmaktadır. Bu durum ülke madenciliğinin geleceği için de umut vermektedir. 2012 yılında gerçekleşen iş kazalarının \% 13,31'i madencilik sektöründe meydana gelmiştir. Bu oran yıllara göre düzenli bir şekilde azalarak, 2016 y1lında \% 4,12'ye kadar düşmüştür. Madencilik sektörünün toplam iş kazaları (tüm sektörler) içerisindeki bu oranının düşüşü çok olumlu ve umut verici bir gelişmedir.

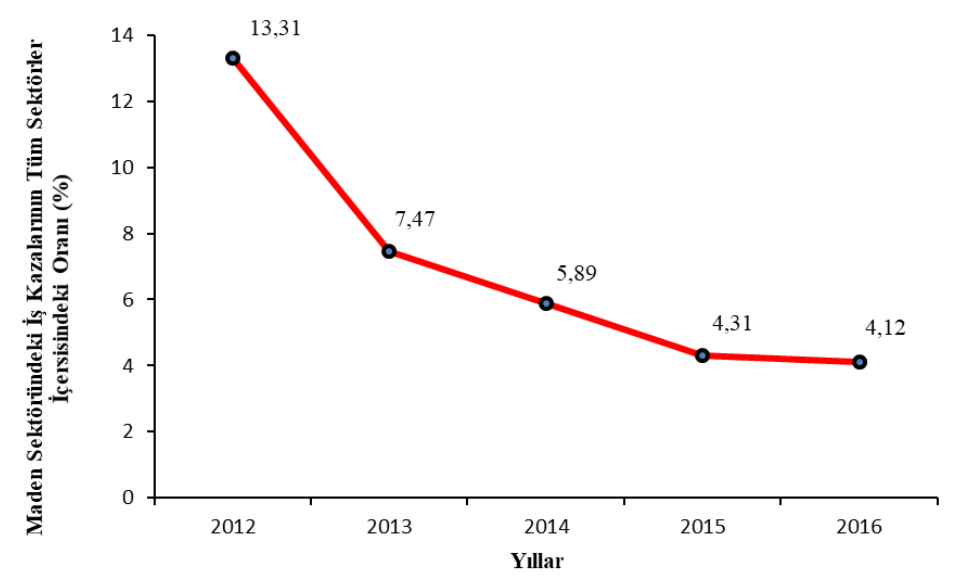

Şekil 3. Madencilik sektöründe gerçekleşen iş kazalarının tüm iş kazaları içerisindeki yüzdesi

Madencilik faaliyetleri kapsamında son beş yıl içerisinde (2012-2016) gerçekleşen iş kazası ve meslek hastalıklarının dağılımı Şekil 4'te sunulmuştur. Son beş yıl içerisinde gerçekleşen toplam iş kazası ve toplam meslek hastalıklarına yakalanan kişiler arasında çok büyük bir fark olduğu görülmektedir. 


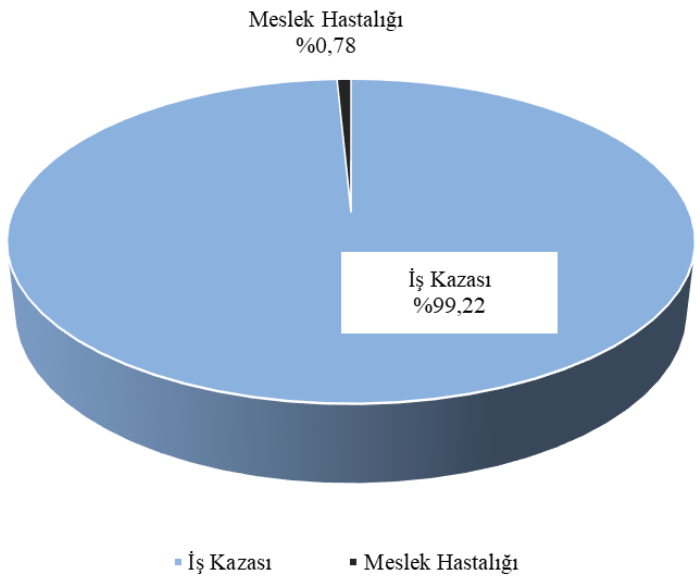

Şekil 4. Son beş yılda madencilik sektöründe gerçekleşen iş kazası ve meslek hastalıklarının dağılımı.

En fazla iş kazalarının gerçekleștiği "Maden, metal-makine ve inşaat sektörü" kaza olabilirlik oranı bakımından incelendiğinde en yüksek kaza olabilirlik oranı madencilik sektöründe olduğu görülmektedir (SGK, 2016). Bu üç işkolu içerisinde toplam gerçekleşen iş kazası sayılarına bakıldığında ise en fazla iş kazası 55949 ile "Metal ve Makine sektörü" de gerçekleşmektedir. Toplam iş kazası bakımından metal ve makine sektörünü 44552 iş kazası ile inşaat sektörü izlemekte ve toplam 11792 iş kazası sayısı ile madencilik sektörü, üçüncü sırada yer almaktadır. Bu işkolları içerisinde kişi başına düşen iş kazası sayısı en fazla madencilik sektöründedir. Madencilik sektöründe çalışan her 100 kişiden yaklaşık 9 tanesi iş kazasına maruz kalmaktadır (Tablo 7).

Tablo 7. Kaza olabilirlik oranına göre bazı sektörlerin karşılaştırılması (SGK, 2016).

\begin{tabular}{|c|c|c|}
\hline Faaliyet Alanı & Toplam İş Kazası Sayısı & $\begin{array}{l}\text { Kaza Olabilirlik Oranı } \\
\text { (Her } 100 \text { kişi başına düşen iş kazası) }\end{array}$ \\
\hline *Madencilik Sektörü & 11792 & 8,90 \\
\hline **Metal ve Makine Sektörü** & 55949 & 5,27 \\
\hline ***İnşaat Sektörü*** & 44552 & 2,36 \\
\hline \multicolumn{3}{|c|}{$\begin{array}{l}\text { *Madencilik Sektörü: Kömür ve linyit çıartılması, Ham petrol ve doğalgaz çıkarımı, Metal cevheri madenciliği, Diğer madencilik ve taş } \\
\text { ocakçılığı, Madenciliği destekleyen hizmetler } \\
\text { **Metal ve Makine Sektörü: Ana metal sanayii, Makine ve teçhizat hariç fabrikasyon metal ürünleri imalatı, Başka yerde sınıflandırılmamış } \\
\text { makine ve ekipman imalatı, Motorlu kara taşıtı, treyler (römork) ve yarı treyler (yarı römork) imalatı, Diğer ulaşım araçlarının imalatı, } \\
\text { Makine ve ekipmanların kurulumu ve onarımı }\end{array}$} \\
\hline
\end{tabular}

\section{Sonuçlar}

Maden sektöründe iş kazalarının azaltılması için, maden işkoluna ait iş kazası verilerinin istatistiksel analizinin yapılması, kaza sebeplerinin belirlenmesi, kaza risklerinin modellenmesi, kaza olasılıklarının tespit edilmesi, iş güvenliği performansının değerlendirilmesi ve buna göre türetilen modellerin sahada uygulanması gerekmektedir. Bu amaç doğrultusunda, bu çalışmada bazı istatistiki analizler yapılarak sorunun çözümüne katkı sağlanmaya çalışılmıştır. Çünkü sektörde meydana gelen kaza durumlarının davranışının daha iyi anlaşılmasına yönelik kaza verilerinin incelenmesi üzerine yapılan çalışmalar, kaza önleyici çalışmalara yön vermede ve aynı tür yeni kazaların oluşumunu önlemede katkı sağlamaktadır.

Son beş yılda madencilik sektöründe meydana gelen iş kazalarının ortalamasına göre bir değerlendirme yapıldığında, iş kazalarının yaklaşık \% 77'si kömür madenciliğinde (Kömür ve linyit 
çıkartması) gerçekleşmiştir. Son beş yıl içerisinde madencilik sektöründe çalışan her 100 kişiden yaklaşık 9'u iş kazasına maruz kalmaktadır. Son yıllarda oranlarda bir düşüş olması ise sevindirici bir gelişmedir.

Maden sektöründe meslek hastalığına yakalanan kişi sayısında genel olarak sabit bir eğilim olduğu gözlenmiştir. Ayrıca, "Ham petrol ve doğal gaz çıkarımı" sektöründe son beş yılda hiçbir meslek hastalığı gerçekleşmemiştir. Meslek hastalığına yakalanma sayısı en fazla taş kömürü madenciliğindedir.

Y1llara göre iş madencilik sektöründe meydana gelen iş kazaları incelendiğinde az da olsa bir azalma eğilimi gösterdiği görülmektedir. Fakat tüm sektörlerde meydana gelen iş kazaları ile kıyaslama yapıldığında daha anlamlı ve olumlu sonuçların elde edildiği görülmektedir. Tüm sektörlerdeki iş kazaları içerisinde madencilik sektöründe gerçekleşen iş kazalarının oranında önemli ve büyük miktarda azalma olduğu görülmektedir. Bu durum ülke madenciliğinin geleceği için de umut vermektedir.

En fazla iş kazasının metal makine sektöründe geçekleşmektedir. Fakat kişi başına düşen iş̧ kazası oranlarına (kaza olabilirlik oranı) göre bir değerlendirme yapıldığında, maden sektörü birinci sırada gelmektedir (metal-makine, maden ve inşaat sektörleri kıyaslandığında).

Ülkemiz madencilik sektöründe iş kazalarının istenilen seviyelerde azaltılamamasının birçok sebebi bulunmaktadır. Bu sebeplerin bazılarının değiştirilmesi bazen çok zor hatta bazen imkânsızdır (ülkemizdeki madenlerdeki zor jeolojik yapı gibi). Fakat bazı parametrelerin değiştirilmesi nispeten daha kolaydır. Dolayısıyla kolay müdahale edilebilir parametrelerin düzeltilmesi kısa sürece iş kazası meslek hastalıklarında azalmaya neden olacaktır. Maden sektöründe, güvenlik kültürünün öneminin farkına varılması mekanize kazı sistemine geçilmesi en kolay parametreler olarak sayılabilir.

Sonuçta, maden sektöründe meydana gelen iş kazaları ve meslek hastalıkları yıllara göre azalma yönünde bir eğilim göstermiş olmasına rağmen, istenilen ve umut edilen seviyelerde değildir. Tüm paydaşların ortak çalışmaları ve özenli davranışlarıyla iş kazaları ve meslek hastalıklarını istenilen ve beklenilen seviyelere düşürmek, kısa süre içerisinde bun ulaşılabileceğine yönelik olumlu göstergeler bulunmaktadır.

\section{Kaynaklar}

[1] Bilim N., Dursun A.E., Bilim A. 2015. Maden ekipmanlarına bağlı iş kazalarının genel değerlendirmesi ve çözüm önerileri, Türkiye 5. Uluslararası Maden Makinaları Sempozyumu ve Sergisi, Eskişehir-Türkiye, 1-12, 1-2 Ekim.

[2] Civelekler E. 2012. Bir manyezit işletmesinde hata türü ve etkileri analizi yöntemi ile iş sağlığı ve güvenliği risk analizi, Yüksek Lisans Tezi, Eskişehir Osmangazi Üniversitesi, Fen Bilimleri Enstitüsü, Eskişehir.

[3] Uyanık T. 2010. Mining Industry in Turkey. IGEME. Export Promotion Center of Turkey, 8p.

[4] Mobbs P.M. 2012. The Mineral Industry of Turkey. USGS Science for Changing World. 2012 Minerals Yearbook, 14p.

[5] Bilim N. 2015. Kömür Madenlerinde Meydana Gelen İş Kazalarının İstatistiksel Değerlendirilmesi, Madencilik Türkiye, 6 (44): 78-82.

[6] Mahdevari S., Shahriar K., Esfahanipour A. 2014. Human health and safety risks management in underground coal mines using fuzzy TOPSIS, Science of the Total Environment. 488-489, 85-99.

[7] Khanzode V.V., Maiti J., Ray P.K. 2011. A methodology for evaluation and monitoring of recurring hazards in underground coal mining, Safety Science, 49 (8-9): 1172-1179.

[8] SGK, 2018. Sosyal Güvenlik Kurumu istatistik y1llikları. http://www.sgk.gov.tr/wps/portal/sgk/tr/kurumsal/istatistik/sgk_istatistik_yilliklari. (Erişim tarihi: 16.02. 2018).

[9] Bayraktar B., Uyguçgil H., Konuk A. 2017. Türkiye madencilik sektöründe iş kazalarının istatiksel analizi, Uluslararası Maden İşletmelerinde İşçi Sağlığı Ve İş Güvenliği Sempozyumu, AdanaTürkiye, 147-160, 2-3 Kasım.

[10] Arıtan A.E., Ataman, M. 2017. Kaza Oranları Hesaplamalarıyla İş Kazası Analizi, Afyon Kocatepe Üniversitesi Mühendislik Bilimleri Dergisi, 17 (1): 239-246.

[11] Ceylan H. 2012. Analysis of Occupational Accidents According to The Sectors in Turkey, Gazi University Journal of Science, 25 (4): 909-918. 
[12] ILO, 2018. Safety and health at work. http://www.ilo.org/global/topics/safety-and-health-atwork/lang--en/index.html. (Erişim tarihi: 18.02. 2018).

[13] Erginel N., Toptancı Ş. 2017. İş kazası verilerinin olasılık dağılımları ile modellenmesi. Mühendislik Bilimleri ve Tasarım Dergisi, 5 (ÖS: Ergonomi2016): 201-212. 